\title{
Characteristics of Prey Environment during the Early Ocean Life of Juvenile Chum Salmon in Two Coastal Areas around Hokkaido, Northern Japan
}

\author{
Tomoki Sato, Toshihiko Saito, Kentaro Honda, and Kyuji Watanabe \\ Salmon Research Department, Fisheries Resources Institute, Japan Fisheries Research and Education Agency, \\ 2-2, Nakanoshima, Toyohira-ku, Sapporo, Hokkaido, 062-0922, Japan
}

Keywords: zooplankton community structure, coastal area, juvenile chum salmon

The early life stage of juvenile chum salmon in the ocean is a critical period in their life history. Their growth and survival in coastal waters are largely affected by physical factors, such as temperature, salinity, and ocean currents. Furthermore, since the quality and quantity of zooplankton as a prey source regulates juvenile growth, clarifying the characteristics of zooplankton used by juvenile chum salmon is important for growth and survival. To evaluate the prey environment during the early life stage of juvenile chum salmon in the ocean, we investigated the temporal dynamics of zooplankton community structure from spring to early summer in two coastal areas of Hokkaido, northern Japan. The first area was off Atsuta on the coast of the Sea of Japan, and the second was off Konbumori on the eastern Pacific coast.

Zooplankton sampling in the Atsuta area was conducted every ten days from late March to mid-June and weekly in the Konbumori area from June to July in 2006-2018. Four sampling stations were established in the Atsuta area $\left(43^{\circ} 23^{\prime}-24^{\prime} \mathrm{N}, 141^{\circ} 18^{\prime}-25^{\prime} \mathrm{E}\right)$ at $0.5,1.0,2.0$ and $10 \mathrm{~km}$ from the shore, and four stations were established in the Konbumori area $\left(42^{\circ} 52^{\prime}-56^{\prime} \mathrm{N}, 144^{\circ} 33^{\prime}-35^{\prime} \mathrm{E}\right)$ at $0.4,1.3,3.5$, and $7.8 \mathrm{~km}$ from the shore. Zooplankton samples were collected with a NORPAC net $(0.45 \mathrm{~m}$ mouth diameter, $0.33 \mathrm{~mm}$ mesh) using vertical tows from a depth of $20 \mathrm{~m}$ to the surface (if the water depth was less than $20 \mathrm{~m}$, the net was towed from near the sea bottom to the surface). Water temperature and salinity were recorded at each sampling station using a CTD (RINKO-Profiler; JFE-Advantech Co. Ltd., Japan.) from the surface to the bottom at 1-m intervals. The analysis of zooplankton community structure was referred to Kaga et al. (2016). The zooplankton community data among stations in all years was ordinated by nonmetric multidimensional scaling based on the Morisita-Horn similarity index. Clustering was performed using the $k$-mean method, with the optimal number of clusters estimated using the Caliński criterion (Caliński and Harabasz 1974). In addition, indicator species analysis was performed to identify indicator species in each cluster (Dufréne and Legendre 1997). These analyses were conducted using the vegan package (v.2.5-7, Oksanen et al. 2020) and labdsv package (v.2.0-1, David 2019) implemented in R statistical software (v.3.6.3, R Core Team 2020).

In both areas, zooplankton typically consisted of copepods, amphipods, euphausiids, cladocerans, hydrozoans, appendicularians, chaetognaths, and meroplanktonic larvae (organisms that are planktonic for only a part of their life cycle) such as gastropods, polychaetes, decapods, and echinoderms. Cluster analysis based on zooplankton abundance revealed that the zooplankton community structure in the Atsuta area could be classified into three groups: warm-water species of copepods and meroplankton dominated-group, cold-water species of copepods dominated-group and euphausiids and hydrozoans dominated-group. On the other hand, the community structure in the Konbumori area could be classified into two groups: cladocerans and warm-water species of copepods dominated-group, and cold-water species of copepods dominated-group. Zooplankton community structure in both areas generally varied as the season progressed, i.e., from cold-water species in spring to warm-water species in early summer. However, in recent years, warm-water species have tended to be dominant in the Konbumori area from early spring. In terms of body size, zooplankton in both areas tended to shift from large to smaller species as the water temperature increased. Cold-water zooplankton species are generally large and rich in energy (e.g., Hooff and Peterson 2006; Mackas et al. 2007), whereas the zooplankton in warm areas are typically smaller and nutritionally poor (e.g., Batten and Walne 2011). Bi et al. (2011) reported that the mean abundance of warm oceanic copepods was inversely related to the annual mean abundance of Chinook yearling and Chinook jack returns, suggesting that ocean conditions for Chinook salmon are unfavorable when these warm oceanic copepod species are abundant. Peterson et al. (2017) reported that the survival of Pacific salmon migrating to the sea from coastal streams and large rivers of the Pacific northwest is positively correlated with the availability of an abundant and lipid-rich food source when they first enter the ocean. Similarly, in our study areas of Atsuta and Konbumori, the stomach contents of juvenile chum salmon consisted primarily of large, cold-water zooplankton species (unpublished data). Thus, the earlier appearance and predominance of small, warm-water zooplankton species might not favor the growth and survival of juvenile chum salmon, which require large zooplankton prey for optimal growth in coastal areas.

All correspondence should be addressed to T. Sato. 


\section{REFERENCES}

Batten, S.D., and A.W. Walne. 2011. Variability in northwards extension of warm water copepods in the NE Pacific. J. Plankton. Res. 33: 1643-1653.

Bi, H., W.T. Peterson, J. Lamb, and E. Casillas. 2011. Copepods and salmon: characterizing the spatial distribution of juvenile salmon along the Washington and Oregon coast, USA. Fish. Oceanogr. 20: 125-138.

Caliński, T., and J. Harabasz. 1974. A dendrite method for cluster analysis. Communications in Statistics. 3: 1-27.

Chiba, S., S. D. Batten, T. Yoshiki, Y. Sasaki, K. Sasaoka, H. Sugisaki, and T. Ichuika. 2015. Temperature and zooplankton size structure: climate control and basin-scale comparison in the North Pacific. Ecol. Evol. 5: 968-978.

David, W. R. 2019. labdsv: Ordination and Multivariate Analysis for Ecology package. R package version $2.0-1$. (Available at http://CRAN.R-project.org/package=labdsv)

Dufréne, M., and P. Legendre. 1997. Species assemblages and indicator species: the need for a flexible asymmetrical approach. Ecol Monogr. 67: 345-366.

Hooff, R.C., and W.T. Peterson. 2006. Copepod biodiversity as an indicator of changes in ocean and climate conditions of the northern California current ecosystem. Limnol. Oceanogr. 51: 2607-2620.

Kaga, T., S. Oguma, K. Kasugai, T. Azumaya, S. Montani, T. Arauchi, and M. Fukuwaka. 2016. Characteristics of spring-summer zooplankton community structure and their relationship with environmental factors in Nemuro Bay, eastern Hokkaido. Bulletin on Coastal Oceanography 53: 179-191. (In Japanese with English abstract)

Mackas, D.L., S. Batten, and M. Trudel. 2007. Effects on zooplankton of a warmer ocean: Recent evidence from the Northeast Pacific. Prog. Oceanogr. 75: 223-252.

Oksanen, J.F., G. Blanchet, M. Friendly, R. Kindt, P. Legendre, D. McGlinn, P.R. Minchin, R.B. O'Hara, G.L. Simpson, P. Solymos, M. Henry, H. Stevens, E. Szoecs, H. Wagner. 2020. vegan: Community ecology package. R package version 2.5-7. (Available at http://CRAN.R-project.org/package=vegan)

Peterson, W.T., J.L. Fisher, P. T. Strub, X. Du, C. Risien, J. Peterson, and C. T. Shaw. 2017. The pelagic ecosystem in the Northern California Current off Oregon during the 2014-2016 warm anomalies within the context of the past 20 years. J. Geophys. Res. Oceans. 122: 7267-7290.

R Core Team. 2020. R: A language and environment for statistical computing. R Foundation for Statistical Computing, Vienna, Austria. (Available at https://www.R-project.org/) 